\title{
Growth and aflatoxin production of Aspergillus flavus in fig-based medium: Effect of minerals and chelating agents
}

\section{Aspergillus flavus'un incir bazlı besiyerinde gelişimi ve aflatoksin üretimi: Mineral maddelerin ve şelat ajanlarının etkisi}

\author{
Sule GUNAYDIN ${ }^{1}$ iD, Hakan KARACA ${ }^{2 *}$ iD \\ 1,2Department of Food Engineering, Faculty of Engineering, Pamukkale University, Denizli, Turkey. \\ sulegunaydin@hotmail.com, hkaraca@pau.edu.tr
}

\begin{abstract}
In this study, minerals required for the growth and aflatoxin production of A. flavus were determined. Then, the effectiveness of some chelating agents such as citric acid, phytic acid and ethylenediaminetetraacetic acid (EDTA) in preventing mold growth and toxin production was investigated in a fig-based medium and in two synthetic media, called Czapek-dox agar (CZA) and potato dextrose agar (PDA). A. flavus did not grow in CZA without sodium nitrate during 6-day incubation at 30 ${ }^{\circ} \mathrm{C}$. The absence of the other components (magnesium sulfate, iron sulfate, potassium chloride and potassium phosphate) did not significantly ( $p>0.05)$ affect the growth of the mold. However, the mold produced significantly $(p<0.05)$ higher amounts of aflatoxins in the media without magnesium sulfate and iron sulfate. A. flavus grew faster on fig-based medium and produced higher amounts of aflatoxins in PDA. In all media tested in this study, EDTA was found to be more effective than the other agents in controlling the growth of A. flavus. It was also effective in inhibiting the production of aflatoxins. It was determined that 1.75 mM EDTA reduced aflatoxin production up to 97\% in PDA. Citric and phytic acids could inhibit the growth of the mold only in PDA. All chelating agent reduced aflatoxin production over $90 \%$ in fig-based medium.
\end{abstract}

Keywords: Template mycotoxin, mold, Ethylenediaminetetraacetic acid, Citric acid, Phytic acid, Aflatoxin, Aspergillus flavus.

\section{Introduction}

Mycotoxins are toxic metabolites of some mold species that can grow on food and feed. Aflatoxins are important mycotoxins produced by some toxigenic Aspergillus strains such as A. flavus and $A$. parasiticus. Many aflatoxin types have been identified but generally six of them, called aflatoxin $B_{1}, B_{2}, G_{1}, G_{2}, M_{1}$ and $\mathrm{M}_{2}$ are regarded as potential food toxicants [1]. These toxins have mutagenic, teratogenic and carcinogenic effects on humans and animals. For instance, aflatoxin $B_{1}$ has been classified as "Group-I carcinogen" which means that there is sufficient evidence of carcinogenicity for this agent [2]. Due to their toxic properties, the permitted amounts of aflatoxins in various food products have been restricted by the legislation in many countries. These restrictions are generally based on the total aflatoxin content (sum of aflatoxins $B_{1}, B_{2}, G_{1}, G_{2}$ ) and the aflatoxin $\mathrm{B}_{1}$ content alone, since it is the most toxic compound among others.

\begin{abstract}
Öz
Bu çalışmada, A. flavus küfünün gelișmesi ve aflatoksin üretmesi için ihtiyaç duyduğu mineral maddeler tespit edilmistir. Daha sonra, sitrik asit, fitik asit, etilendiamintetraasetik asit (EDTA) gibi bazı şelat ajanlarının; incir-bazlı bir ortam, Czapek-dox agar (CZA) ve patates dekstroz agar (PDA) besiyerlerinde küfün gelişmesi ve toksin üretmesini önlemedeki etkinliği araștırılmıștır. Sodyum nitrat içermeyen CZA besiyerinde $30^{\circ} \mathrm{C}^{\prime}$ deki 6 günlük inkübasyon süresince A. flavus küfünün hiç gelișmediği saptanmıștır. Diğer bileșenlerin (magnezyum sülfat, demir sülfat, potasyum klorür ve potasyum fosfatın) besiyerinde bulunmaması, küfün gelişimini istatistiksel olarak anlamlı bir şekilde etkilememiștir $(p>0.05)$. Ancak magnezyum sülfat ve demir sülfat içermeyen besiyerlerinde istatistiksel olarak anlaml düzeyde yüksek miktarlarda aflatoksin üretimi gözlenmiștir $(p<0.05)$. A. flavus küfü, incir-bazlı ortamda daha hızlı gelișmiș ve PDA besiyerinde daha yüksek miktarda aflatoksin üretmiștir. Denenen tüm besiyerlerinde, EDTA, A. flavus gelișimini kontrol etmede diğer ajanlara göre daha etkili olmuştur. Ayrıca bu ajan, aflatoksin üretimini inhibe etmede de etkili bulunmuștur. Söz konusu ajanın 1.75 mM'lk konsantrasyonu, PDA besiyerinde aflatoksin üretimini \%97'ye varan oranlarda azaltmıştır. Sitrik asit ve fitik asit küf gelișimini sadece PDA besiyerinde inhibe edebilmiștir. Denenen tüm șelat ajanları, incir-bazlı ortamda aflatoksin üretimini \%90'ın üzerinde azaltmıștır.
\end{abstract}

Anahtar kelimeler: Mikotoksin, küf, Etilendiamintetraasetik asit, Sitrik asit, Fitik asit, Aflatoksin, Aspergillus flavus.

It is known that molds, like other microorganisms, depend on various factors such as energy source, water, oxygen, etc. for their growth. Minerals such as sodium, potassium, magnesium, etc. are also needed for various metabolic activities of the organism. Actually, molds have minimal growth requirements compared to other microorganisms. They may grow in a wide range of $\mathrm{pH}$ [3] and at low water activity levels [4].

Fig fruit is quite susceptible to the attacks of microorganisms including toxigenic molds. There are many critical steps in the course of dried fig production in terms of mold contamination and aflatoxin production. As a result, dried figs are among the commodities that are often reported due to the contamination with aflatoxins [5]-[7]. Aflatoxin contamination has become a chronic problem of the dried fig producer countries like Turkey, Greece, Spain, Italy, the US, etc. for decades. It constitutes not only an economic problem for the exporters but also a health risk for the consumers of the product.

${ }^{*}$ Corresponding author/Yazışılan Yazar 
It is obvious that preventing mold contamination and aflatoxin production is the most reasonable solution to aflatoxin problem in dried figs as well as other commodities. There are quite a few studies that have demonstrated the antifungal effects of some chelating agents that are widely used in food applications. Citric acid and ethylenediaminetetraacetic acid (EDTA) have been recently tested for their antifungal potential [8]-[12]. Many factors such as treatment dose, temperature, fungal strain and the medium in which the cheating process takes place determine the effectiveness of the chelating agents in controlling mold growth and toxin production. Although dried figs are risky commodities in terms of aflatoxin contamination, as yet there are no studies examining the effectiveness of common chelating agents for controlling growth and aflatoxin production of toxigenic Aspergillus strains in figs or a fig-based medium.

The objective of the present study was to determine the mineral(s) required by toxigenic $A$. flavus for its growth and aflatoxin production. It was also aimed to evaluate the effectiveness of citric acid, phytic acid and EDTA in controlling the growth and aflatoxin production of the mold in different media including a fig-based medium.

\section{Material and methods}

\subsection{Fungal strain and chemicals}

A. flavus was chosen as the fungal species to be used in the study since it was previously shown as the dominant species in the fungal flora of the major fig production area in Turkey [13]. The toxigenic strain used in the study (MAM-200682) was obtained from Mold Culture Collection of the Scientific and Technological Research Council of Turkey (TUBITAK). The strain was maintained at $-70{ }^{\circ} \mathrm{C}$ in $60 \%$ glycerol until use and activated on PDA at $30^{\circ} \mathrm{C}$ for $7 \mathrm{~d}$ before the experiments.

The microbiological media used in the study (potato dextrose agar [PDA] and Czapek-dox agar [CZA]) were obtained from Merck (Darmstadt, Germany). Sodium nitrate $\left(\mathrm{NaNO}_{3}\right)$, sodium hydroxide $(\mathrm{NaOH})$, disodium hydrogen phosphate dihydrate $\left(\mathrm{Na}_{2} \mathrm{HPO}_{4} .2 \mathrm{H}_{2} \mathrm{O}\right)$ and nitric acid $\left(\mathrm{HNO}_{3}\right)$ were also purchased from Merck. Potassium chloride $(\mathrm{KCl})$, potassium phosphate monobasic $\left(\mathrm{KH}_{2} \mathrm{PO}_{4}\right)$, sodium chloride $(\mathrm{NaCl})$, potassium bromide $(\mathrm{KBr})$, methanol and agar-agar were obtained from Sigma-Aldrich Chemie GmbH (Steinheim, Germany). Iron (III) sulfate pentahydrate $\left(\mathrm{Fe}_{2}\left(\mathrm{SO}_{4}\right)_{3} .5 \mathrm{H}_{2} \mathrm{O}\right)$ and ethylenediaminetetraacetic acid (EDTA) were purchased from Fisher Scientific (Pittsburgh, PA, USA). Disodium EDTA ( $\mathrm{Na}_{2}-$ EDTA) was obtained from BioShop (Burlington, Ontario, Canada). Magnesium sulfate heptahydrate $\left(\mathrm{MgSO}_{4} \cdot 7 \mathrm{H}_{2} \mathrm{O}\right)$ and citric acid were from Scharlau (Barcelona, Spain). Phytic acid ( $50 \%$ in water) and sucrose were obtained from Acros Organics (Geel, Belgium) and Caisson Laboratories (Logan, UT, USA), respectively.

\subsection{Preparation of modified media and measurement of mycelial growth}

In order to investigate the effects of minerals on growth and aflatoxin production of $A$. flavus, CZA, which contains all the minerals as separate ingredients, was chosen as a model medium. Originally, the composition of CZA was (for $100 \mathrm{~mL}$ ): $3 \mathrm{~g}$ sucrose, $0.3 \mathrm{~g} \mathrm{NaNO}, 0.1 \mathrm{~g} \mathrm{MgSO}_{4} .7 \mathrm{H}_{2} \mathrm{O}, 0.0012 \mathrm{~g}$ $\mathrm{Fe}_{2}\left(\mathrm{SO}_{4}\right)_{3} .5 \mathrm{H}_{2} \mathrm{O}, 0.05 \mathrm{~g} \mathrm{KCl}, 0.125 \mathrm{~g} \mathrm{KH}_{2} \mathrm{PO}_{4}$ and $1.3 \mathrm{~g}$ agar-agar [14]. In order to prepare the modified media, aqueous stock solutions of $\mathrm{NaNO}_{3}, \mathrm{MgSO}_{4} .7 \mathrm{H}_{2} \mathrm{O}, \mathrm{Fe}_{2}\left(\mathrm{SO}_{4}\right)_{3} .5 \mathrm{H}_{2} \mathrm{O}, \mathrm{KCl}$ and $\mathrm{KH}_{2} \mathrm{PO}_{4}$ were prepared.

It is known that Aspergillus spp. use $\mathrm{NaNO}_{3}, \mathrm{MgSO}_{4} .7 \mathrm{H}_{2} \mathrm{O}$, $\mathrm{Fe}_{2}\left(\mathrm{SO}_{4}\right)_{3} .5 \mathrm{H}_{2} \mathrm{O}$ as sources of sodium, magnesium and iron, respectively [15],[16] and therefore modified media were prepared by omitting one of these ingredients. In the case for potassium, two ingredients $\left(\mathrm{KCl}\right.$ and $\left.\mathrm{KH}_{2} \mathrm{PO}_{4}\right)$ were tested. A detailed description of the modified media prepared is given in Table 1 . All the media were prepared in borosilicate glass bottles, sterilized by autoclaving for $15 \mathrm{~min}$ at $121{ }^{\circ} \mathrm{C}$, cooled and then poured into plastic petri dishes, $85 \mathrm{~mm}$ in diameter. Five replicate plates were used for each modification.

Table 1. Detailed description of modified media prepared.

\begin{tabular}{|c|c|}
\hline Modification & Content of the modified media \\
\hline None (control) & $\begin{array}{c}\text { sucrose, } \mathrm{NaNO}_{3}, \mathrm{MgSO}_{4} .7 \mathrm{H}_{2} \mathrm{O} \\
\mathrm{Fe}_{2}\left(\mathrm{SO}_{4}\right)_{3} .5 \mathrm{H}_{2} \mathrm{O}, \mathrm{KCl}, \mathrm{KH}_{2} \mathrm{PO}_{4} \text {, agar- } \\
\text { agar and distilled water }\end{array}$ \\
\hline Omitting $\mathrm{NaNO}_{3}$ & $\begin{array}{c}\text { sucrose, } \mathrm{MgSO}_{4} .7 \mathrm{H}_{2} \mathrm{O} \\
\mathrm{Fe}_{2}\left(\mathrm{SO}_{4}\right)_{3} .5 \mathrm{H}_{2} \mathrm{O}, \mathrm{KCl}, \mathrm{KH}_{2} \mathrm{PO}_{4} \text {, agar- } \\
\text { agar and distilled water }\end{array}$ \\
\hline Omitting $\mathrm{MgSO}_{4} .7 \mathrm{H}_{2} \mathrm{O}$ & $\begin{array}{c}\text { sucrose, } \mathrm{NaNO}_{3}, \mathrm{Fe}_{2}\left(\mathrm{SO}_{4}\right)_{3} .5 \mathrm{H}_{2} \mathrm{O} \\
\mathrm{KCl}, \mathrm{KH}_{2} \mathrm{PO}_{4} \text {, agar-agar and } \\
\text { distilled water }\end{array}$ \\
\hline Omitting & sucrose, $\mathrm{NaNO}_{3}, \mathrm{MgSO}_{4} .7 \mathrm{H}_{2} \mathrm{O}, \mathrm{KCl}$, \\
\hline $\mathrm{Fe}_{2}\left(\mathrm{SO}_{4}\right)_{3 .} .5 \mathrm{H}_{2} \mathrm{O}$ & $\begin{array}{c}\mathrm{KH}_{2} \mathrm{PO}_{4} \text {, agar-agar and distilled } \\
\text { water }\end{array}$ \\
\hline Omitting $\mathrm{KCl}$ & $\begin{array}{c}\text { sucrose, } \mathrm{NaNO}_{3}, \mathrm{MgSO}_{4} .7 \mathrm{H}_{2} \mathrm{O} \\
\mathrm{Fe}_{2}\left(\mathrm{SO}_{4}\right)_{3} .5 \mathrm{H}_{2} \mathrm{O}, \mathrm{KH}_{2} \mathrm{PO}_{4} \text {, agar-agar } \\
\text { and distilled water }\end{array}$ \\
\hline Omitting $\mathrm{KH}_{2} \mathrm{PO}_{4}$ & $\begin{array}{c}\text { sucrose, } \mathrm{NaNO}_{3}, \mathrm{MgSO}_{4} .7 \mathrm{H}_{2} \mathrm{O}, \\
\mathrm{Fe}_{2}\left(\mathrm{SO}_{4}\right)_{3} .5 \mathrm{H}_{2} \mathrm{O}, \mathrm{KCl} \text {, agar-agar and } \\
\text { distilled water }\end{array}$ \\
\hline
\end{tabular}

The radial growth of $A$. flavus in different media during incubation was measured using a method suggested by Karaca et al. [17]. Briefly, the center of the medium in the petri dish was inoculated with mycelial plugs which were extracted using the back end of a sterilized Pasteur pipette (5 $\mathrm{mm}$ in diameter) from 7-day-old $A$. flavus cultures. Then, the dishes were incubated at $30^{\circ} \mathrm{C}$ for up to 6 days. The radial mycelial growth $(\mathrm{mm})$ in each plate was determined on the $2^{\text {nd }}, 4^{\text {th }}$ and $6^{\text {th }}$ days of incubation. Fungal colony diameters were measured vertically and horizontally and the averages were calculated.

\subsection{Assessment of mycelial growth and aflatoxin production of $A$. flavus in different media}

To determine the most appropriate medium for growth and aflatoxin production of $A$. flavus, experiments were conducted on fig-extract agar, CZA and PDA.

Fig-extract agar was prepared based on the formulation of PDA medium. Originally, the composition of the PDA medium consists of potato infusion (200 g), dextrose (20 g), agar-agar $(20 \mathrm{~g})$ and distilled water $(1 \mathrm{~L})$ [18]. It is obvious that the minerals required for the growth of the mold are provided from the potato infusion in this medium. For the preparation of figextract agar, dried fig extract was used instead of the potato infusion in the formulation of PDA.

Aflatoxin- and additive-free dried figs were kindly supplied from a local market in Denizli, Turkey, cut into small pieces and boiled for $30 \mathrm{~min}$ in $1 \mathrm{~L}$ of distilled water in a pot. The amount of dried figs to be used for boiling was determined according to the results of a preliminary experiment conducted to test different amounts $(150,200,250 \mathrm{~g})$ of dried figs. Since the 
amount of dried figs used in this step did not affect the growth of the mold, we decided to use $200 \mathrm{~g}$ of dried figs, the equivalent amount of potatoes in the PDA formulation. After boiling, the content of the pot was filtered through cheesecloth and $20 \mathrm{~g}$ of agar-agar (the same amount in PDA) was added. Since the sugar content of the dried figs is quite high [19], no additional sugar (dextrose or sucrose) was added to the medium. The medium, which was prepared as described above, was sterilized $\left(121^{\circ} \mathrm{C}\right.$, $15 \mathrm{~min}$ ), poured into petri dishes and cooled to room temperature. Flow chart for preparation of fig-extract agar medium is given in Figure 1. The fig-extract agar medium, also PDA and CZA, were inoculated and incubated as described above and the radial mycelial growth was measured periodically during incubation. Aflatoxin analyses were conducted at the end of incubation period.

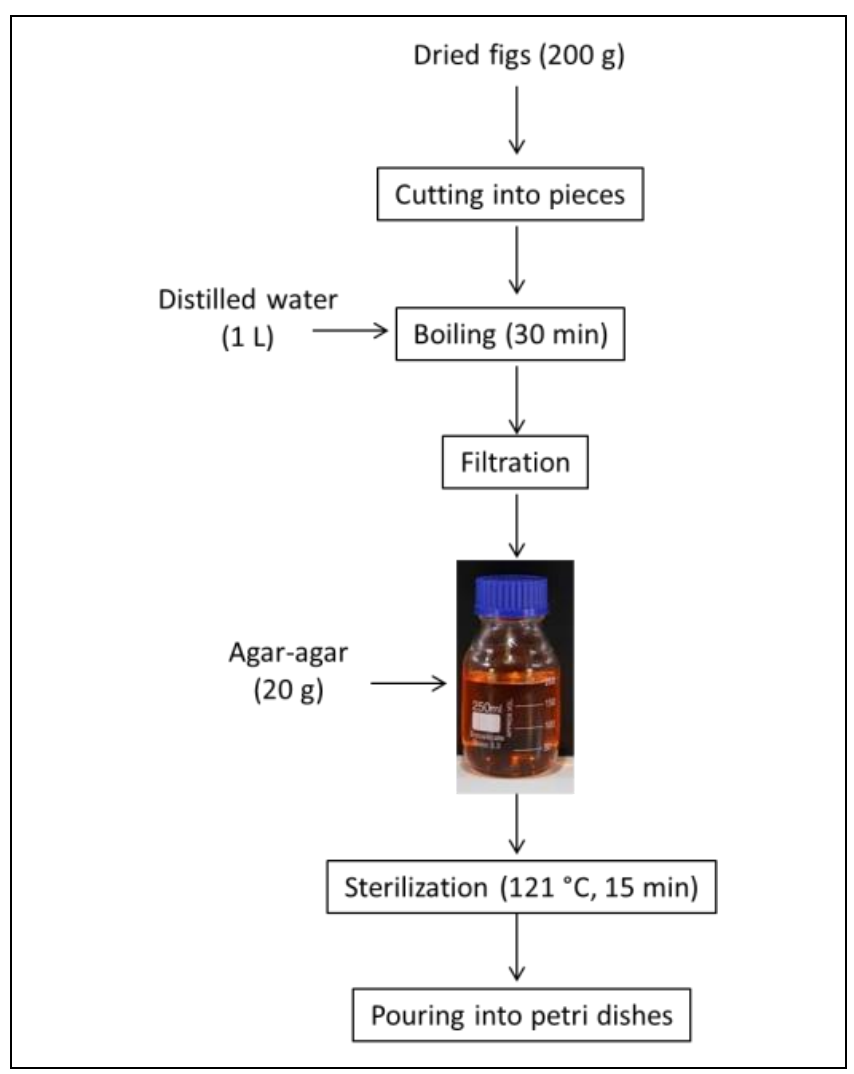

Figure 1. Flow chart for preparation of fig-extract agar medium.

\subsection{Assessment of the effects of chelating agents on mycelial growth and aflatoxin production of $A$. flavus in different media}

Efficacy of chelating agents in controlling growth and aflatoxin production of $A$. flavus in different media was studied. The three media used for this purpose were CZA, PDA and fig-extract agar. The agents (citric acid, phytic acid and EDTA) tested in this experiment were selected as they are commonly used for chelating purposes in food applications.

Determination of the concentrations of the chelating agents was based on the concentration of $\mathrm{NaNO}_{3}$ in CZA as it was the most abundantly found compound in this medium. The concentration of this compound was calculated in millimolar (mM) and, 0.025 and 0.25 fold of this value were determined as the minimum and maximum concentrations, respectively, of the chelating agents to be tested in the experiments.
Accordingly, $0.175,0.875$ and $1.75 \mathrm{mM}$ of citric acid and EDTA were tested. Since a solidification problem was observed when $1.75 \mathrm{mM}$ phytic acid was added to the medium, the concentrations to be tested for this agent were determined as $0.175,0.438$ and $0.875 \mathrm{mM}$. Stock solutions of the chelating agents were prepared and appropriate volumes of these solutions (corresponding concentrations) were added to each medium. Media without chelating agents served as controls.

A. flavus growth in different media with or without chelating agents was monitored during incubation according to the procedure described above. Five replicate plates were used for each chelating agent and the agent concentration. The results were expressed as the percentage of radial mycelial growth inhibition according to the formula: (dc-dt) / dc x 100. Here, dc is the average diameter of the fungal colony on control plates and $\mathrm{dt}$ is the average diameter of the fungal colony on chelating agent-amended plates. Aflatoxin analyses were conducted at the end of incubation period.

\subsection{Analysis of aflatoxins}

In the literature, it was reported that $A$. flavus produced the maximum amount of aflatoxins within 5-7 days at $30{ }^{\circ} \mathrm{C}$ [20]. After conducting experiments with A. flavus contaminated peanuts, Ellis et al. [21] reported that maximum toxin production occurred after 21 days of storage at $25^{\circ} \mathrm{C}$. In the light of these data, all aflatoxin analyses in the present study were carried out after an incubation period of 21 days at $30^{\circ} \mathrm{C}$.

Aflatoxins in the samples were determined according to official procedures (AOAC 999.07) with slight modifications [22]. Briefly, the content of the petri dish (approximately $20 \mathrm{~g}$ ) was transferred to a Waring blender and $2.5 \mathrm{~g}$ of sodium chloride, $7.5 \mathrm{~mL}$ of distilled water and $70 \mathrm{~mL}$ of methanol were added. After blending for $1 \mathrm{~min}$, the content of the blender was filtered through coarse filter paper. A portion of the filtrate $(5 \mathrm{~mL})$ was diluted with $10 \mathrm{~mL}$ of phosphate buffer solution (PBS). The PBS had been previously prepared by solving $8 \mathrm{~g} \mathrm{NaCl}, 0.2 \mathrm{~g} \mathrm{KCl}, 0.2$ $\mathrm{g} \mathrm{KH}_{2} \mathrm{PO}_{4}$ and $1.45 \mathrm{~g} \mathrm{Na}_{2} \mathrm{HPO}_{4}$ in $1000 \mathrm{~mL}$ distilled water and adjusted to $\mathrm{pH} 7.4$ with $\mathrm{NaOH}$.

The diluted extract $(15 \mathrm{~mL})$ was applied to immunoaffinity column (Aflatest, Vicam Watertown, MA, USA) at a steady state flow rate of approximately $3 \mathrm{~mL} / \mathrm{min}$. Then, the column was washed with distilled water $(10 \mathrm{~mL})$ twice at a flow rate of 5 $\mathrm{mL} / \mathrm{min}$. After passing air through the column with a syringe for several times, the aflatoxins were eluted by applying $1 \mathrm{~mL}$ of high pressure liquid chromatography (HPLC) grade methanol and $1 \mathrm{~mL}$ of bidistilled water. The eluate was collected in an amber vial and used in HPLC analysis.

Analysis of aflatoxins was carried out using an HPLC system (Shimadzu LC-20AD, Kyoto, Japan) consisting of a pump (Shimadzu LC-20A), a degasser (Shimadzu DGU-20A), a column oven (Shimadzu CTO-20A) and a fluorescence detector (Shimadzu RF-20A). The column oven was set at $25^{\circ} \mathrm{C}$ and the fluorescence detector was set at an excitation wavelength of $360 \mathrm{~nm}$ and an emission wavelength of $430 \mathrm{~nm}$. The analytical column was ODS 2 Hypersil $(3 \mu \mathrm{m}, 150 \times 4.6 \mathrm{~mm}$ I.D., Thermo Scientific, Waltham, MA, USA). A post-column derivatization was employed using an electrochemical derivatization device (Coring System Diagnostix GmbH, Gernsheim, Germany). The mobile phase was methanol:water $(40: 60, \mathrm{v} / \mathrm{v})+216 \mathrm{mg} \mathrm{KBr}+$ $636 \mu \mathrm{L} 4 \mathrm{M} \mathrm{HNO}_{3}$ at a constant flow rate of $1 \mathrm{~mL} / \mathrm{min}$. A loop with $20 \mu \mathrm{L}$ volume was used for sample injections. 
A series of standard solutions were prepared from a mixed standard solution of aflatoxins (Supelco, Bellefonte, PA, USA; containing $1,0.29,0.99$ and $0.27 \mu \mathrm{g}$ of aflatoxins $\mathrm{B}_{1}, \mathrm{~B}_{2}, \mathrm{G}_{1}$ and $\mathrm{G}_{2}$, respectively, in $1 \mathrm{~mL}$ of methanol) by appropriate dilutions in methanol. These solutions were used to prepare five-point calibration curves with concentrations of 2-10, 0.58-2.9, 1.989.9 and 0.54-2.7 $\mu \mathrm{g} / \mathrm{L}$ aflatoxins $\mathrm{B}_{1}, \mathrm{~B}_{2}, \mathrm{G}_{1}$ and $\mathrm{G}_{2}$, respectively. These calibration curves were used to quantify aflatoxins produced in the media. Triplicate injections were made for each concentration. Other calibration curves were prepared using low concentrations of aflatoxins to determine the limit of detection (LOD) and the limit of quantification (LOQ) of the method. These curves covered the ranges of $0.025-0.5,0.0075-$ $0.145,0.2475-0.495$ and $0.00675-0.135 \mu \mathrm{g} / \mathrm{L}$ for aflatoxins $\mathrm{B}_{1}$ $\mathrm{B}_{2}, \mathrm{G}_{1}$ and $\mathrm{G}_{2}$, respectively. LOD and LOQ values were calculated by the calibration curves and the following equations:

$$
\begin{aligned}
& L O D=\frac{3.3 \times S D}{m} \\
& L O Q=\frac{10 \times S D}{m}
\end{aligned}
$$

Here, SD is the standard deviation of the response and $m$ is the slope of the calibration curve. LOD and LOQ values were determined as 0.03 and $0.1 \mu \mathrm{g} / \mathrm{L}$ for aflatoxin $\mathrm{B}_{1}, 0.005$ and 0.01 $\mu \mathrm{g} / \mathrm{L}$ for aflatoxin $\mathrm{B}_{2}, 0.02$ and $0.07 \mu \mathrm{g} / \mathrm{L}$ for aflatoxin $\mathrm{G}_{1}$ and 0.01 and $0.03 \mu \mathrm{g} / \mathrm{L}$ for aflatoxin $\mathrm{G}_{2}$, respectively. For recovery tests, medium samples were spiked with standard solution of aflatoxins (to a final aflatoxin $B_{1}$ concentration of $1 \mathrm{ng} / \mathrm{g}$ ). The samples were let to settle for $15 \mathrm{~min}$ and then the extraction and injection procedures were conducted as described above. Triplicate injections were made and recovery values were calculated. The average recovery values for aflatoxins $B_{1}, B_{2}, G_{1}$ and $\mathrm{G}_{2}$ were $87 \%, 60 \%, 120 \%$ and $85 \%$, respectively. The results given in the present study were corrected for the average recovery values.

\section{$2.6 \mathrm{pH}$ measurement}

The $\mathrm{pH}$ values of all the media used in this study were measured with a bench-top pH-meter (HI 2211 pH/ORP Meter, HANNA Instruments, USA). Three measurements were recorded for each medium.

\subsection{Statistical analysis}

Statistical evaluations were accomplished using analysis of variance (ANOVA) techniques with the help of a statistical package program (Minitab v. 16, Minitab Inc., State College, PA, USA). Significant differences among means were identified by Tukey's mean test $(\mathrm{p}<0.05)$.

\section{Results and discussion}

\subsection{The effect of the absence of minerals on growth of $A$. flavus}

The effects of the absence of minerals on the growth of A. flavus during $6 \mathrm{~d}$ incubation at $30{ }^{\circ} \mathrm{C}$ are shown in Figure 2. Mean colony diameters measured in control plates on the $2^{\text {nd }}, 4^{\text {th }}$ and $6^{\text {th }}$ days of incubation were $22.80 \pm 7.08,50.88 \pm 4.92$ and $75.80 \pm 4.50 \mathrm{~mm}$, respectively. In the modified media prepared without $\mathrm{MgSO}_{4}, \mathrm{Fe}_{2}\left(\mathrm{SO}_{4}\right)_{3}, \mathrm{KCl}$ or $\mathrm{KH}_{2} \mathrm{PO}_{4}$, these values were 18.20-20.00, 46.20-49.00 and 75.80-76.00 mm, respectively. On the other hand, no growth was observed throughout the $6 \mathrm{~d}$ incubation period in the medium prepared without $\mathrm{NaNO}_{3}$. There were no significant differences among the growth rates determined in control plates and in the modified media ( $p>0.05)$ with the exception of the one without $\mathrm{NaNO}_{3}$. Therefore, it can be concluded that $\mathrm{Mg}$, Fe and $\mathrm{K}$ did not have any positive or negative effect on the growth of $A$. flavus at concentrations found in medium formulation. Whereas early studies stated that the growth of $A$. flavus and A. parasiticus were stimulated by the presence of Mg [23], Fe [24] and K [25]. On the contrary, these minerals and/or their salts were reported to have an inhibitory effect on mold growth above a certain concentration [26]-[28]. But, at low concentrations (i.e. those naturally found in fruits), minerals generally stimulated the growth of some important toxigenic fungi such as

\begin{tabular}{|c|c|c|c|}
\hline Medium & Day 2 & Day 4 & Day 6 \\
\hline Control & & & \\
\hline $\begin{array}{l}\text { CZA without } \\
\mathrm{NaNO}_{3}\end{array}$ & & & \\
\hline $\begin{array}{l}\text { CZA without } \\
\mathrm{MgSO}_{4}\end{array}$ & & & \\
\hline $\begin{array}{l}\text { CZA without } \\
\mathrm{Fe}_{2}\left(\mathrm{SO}_{4}\right)_{3}\end{array}$ & & & \\
\hline $\begin{array}{l}\text { CZA without } \\
\mathrm{KCl}\end{array}$ & & & \\
\hline CZA without & & & \\
\hline
\end{tabular}
Aspergillus [29], Penicillium [30] and Fusarium [31].

Figure 2. The effect of the absence of the minerals on the radial mycelial growth of $A$. flavus during $6 \mathrm{~d}$ incubation at $30^{\circ} \mathrm{C}$.

Another important result obtained in the present study is that A. flavus did not grow in the medium prepared without $\mathrm{NaNO}_{3}$ throughout the 6-d incubation period. To clarify the cause of this observation; different sources of sodium and nitrate, $\mathrm{Na}_{2} \mathrm{SO}_{4}$ and $\mathrm{KNO}_{3}$, respectively, were included separately in the formulation of the media. After the incubation period; there was no difference between the growth rates determined in control plates and in the medium with $\mathrm{KNO}_{3}$ and no growth was observed in the medium prepared with $\mathrm{Na}_{2} \mathrm{SO}_{4}$ (data not shown). These results indicate the dependency of mold growth on nitrate and that $A$. flavus uses $\mathrm{NaNO}_{3}$ as a nitrogen source rather than a sodium source. Various compounds such as amino acids, nitrate, nitrite, urea, ammonia, ammonium nitrate, ammonium sulfate were reported to be used as nitrogen source by $A$. flavus for metabolic activities [32]-[34]. Mehl and Cotty [35] examined the growth of eight genetically distinct $A$. flavus isolates in modified CZA media with varying concentrations of sucrose (8.8-88 $\mathrm{mM}$ ) and $\mathrm{NaNO}_{3}$ (3.5-35 mM), which are the only sources of carbon and nitrogen in the medium, respectively. The authors reported that the competition 
between paired isolates was affected by varying concentrations of carbon and nitrogen. McAlpin and Wicklow [36] examined the growth of Petromyces alliaceus, a fungus classified in Aspergillus section Flavi, on modified CZA media and observed that a greater percentage of the stromata formed ascocarps when the $\mathrm{NaNO}_{3}$ in CZA was replaced with an equivalent amount of available nitrogen supplied by ammonium tartrate, glutamic acid, or serine. Most recently, Wang et al. [37] showed that glutamine amino acid is the optimal nitrogen source for aflatoxin biosynthesis in A. flavus grown in CZA medium.

\subsection{The effects of different media on growth of $\boldsymbol{A}$. flavus}

The effect of medium type on growth of A. flavus during $6 \mathrm{~d}$ incubation at $30^{\circ} \mathrm{C}$ can be seen in Table 2 . On the second day of incubation, the growth of $A$. flavus was significantly slower in CZA than those in the other media $(\mathrm{p}<0.05)$. However, on the following days, the difference between the mold grow rates in CZA and PDA disappeared ( $p>0.05)$. Despite the insignificant difference between the growth rates in PDA and fig-extract agar on the last sampling day, A. flavus grew faster in fig-extract agar than the other media throughout the incubation. It shows that fig-extract agar is a more suitable medium for A. flavus growth than CZA and PDA. After examining a plenty of fruits, Morton et al. [38] indicated that fig serves as a good substrate for $A$. flavus and $A$. parasiticus growth due to its high sugar and rich vitamin and mineral contents. Ikechi-Nwogu and Elenwo [39] inoculated spores of many fungal species (including A. flavus) into potato dextrose and groundnut dextrose broth and incubated at $27{ }^{\circ} \mathrm{C}$ for $7 \mathrm{~d}$. They reported that groundnut dextrose broth supported the growth of all fungi tested better than potato dextrose broth because the former contains more vitamins and minerals vital to fungal growth.

Our results revealed that the growth rate of $A$. flavus varies remarkably on different media. Obviously, it is due to the differences in the composition of different media. Cotty [40] compared four media (Aspergillus flavus/parasiticus agar, rose bengal agar, modified rose bengal agar and CZA) for the isolation of $A$. flavus group fungi. According to the author, modified rose bengal agar is the most useful medium for studying population biology since it does not contain any complex carbon and nitrogen sources.

Table 2. Radial mycelial growth (mm) of A. flavus on CZA, PDA and fig-extract agar during 6-day incubation at $30^{\circ} \mathrm{C}$. a, b.

\begin{tabular}{|c|c|c|c|}
\hline Medium & Day 2 & Day 4 & Day 6 \\
\hline CZA & $16.80 \pm 1.48 \mathrm{c}$ & $\begin{array}{c}43.40 \pm 0.89 \\
b\end{array}$ & $74.00 \pm 1.46 \mathrm{~b}$ \\
\hline PDA & $21.40 \pm 1.82 \mathrm{~b}$ & $\begin{array}{c}50.00 \pm 8,46 \\
\text { b }\end{array}$ & $74.80 \pm 1.30 \mathrm{ab}$ \\
\hline $\begin{array}{c}\text { Fig-extract } \\
\text { agar }\end{array}$ & $32.20 \pm 1.10 \mathrm{a}$ & $\begin{array}{c}74.90 \pm 1.24 \\
\mathrm{a}\end{array}$ & $76.00 \pm 0.01 \mathrm{a}$ \\
\hline
\end{tabular}

\subsection{The effects of chelating agents on growth of $A$. flavus}

The effects of chelating agents on radial growth of $A$. flavus in different media after incubation at $30^{\circ} \mathrm{C}$ are shown in Figure 3 . As can be seen from the figure, citric acid and phytic acid failed to control the growth of $A$. flavus in CZA and fig-extract agar. There were no significant differences among fungal growth rates observed in the presence and absence of these agents in CZA and fig-extract agar media $(p>0.05)$. In parallel to our results, Schultz and Muller [41] reported that citric acid could not inhibit the growth of any molds and yeasts in feedstuffs. However, there are also a number of studies that report the inhibition potential of both citric acid [42],[43] and phytic acid [44],[45].

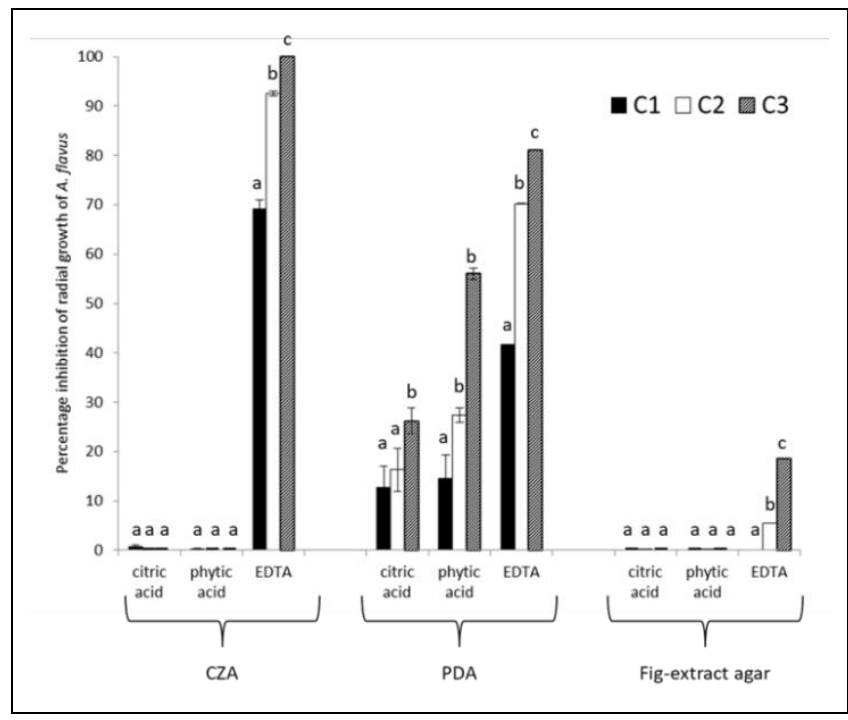

a: C1, C2 and C3 were $0.175,0.875$ and $1.75 \mathrm{mM}$ for citric acid and EDTA and 0.175 , 0.438 and $0.875 \mathrm{mM}$ for phytic acid. Data represent mean values and standard errors of five replicates. For a specific chelating agent tested in a specific medium, values with different letters are significantly different according to Tukey's Multiple Range Test $(\mathrm{p}<0.05)$.

Figure 3. The effects of citric acid, phytic acid and EDTA on the radial growth of $A$. flavus on CZA, PDA and fig-extract agar at the end of incubation at $30^{\circ} \mathrm{C}$ for $6 \mathrm{~d}$. a

According to our results, PDA was the only medium in which citric acid and phytic acid could inhibit the growth of $A$. flavus. In this medium, inhibition rates of $12.7-26.2 \%$ and $14.6-56.0 \%$ were recorded in the presence of citric acid and phytic acid, respectively. Inhibition rates increased as the concentration of the agents increased and the maximum inhibition rates were recorded in the presence of maximum concentrations of both citric acid $(1.75 \mathrm{mM})$ and phytic acid $(0.875 \mathrm{mM})$. Similar inhibition rates were observed by other authors on PDA amended with citric acid. Askarne et al. [46] reported that the growth of Penicillium italicum was inhibited by 29.2 and $55.2 \%$ in PDA amended with 0.02 and $0.2 \mathrm{M}$ citric acid, respectively. Gowda et al. [47] recorded inhibition rates of 36-64\% against $A$. parasiticus in PDA with citric acid. In addition, phytic acid was reported to be effective against Botrytis cinerea [48] in PDA and against Penicillium expansum [49] when used in combination with $P$. caribbica yeast. According to our results, citric acid and phytic acid inhibited the growth of A. flavus in PDA but were not effective against the same mold in two of three media (CZA and fig-extract agar) tested in this study. These results show that antifungal potentials of these chelating agents are strongly related to the content and distribution of the minerals of the medium where the mold grows. In our case, most of the compounds present in CZA and fig-extract media could not be chelated by citric acid or phytic acid. On the other hand, some important compounds required for the growth of $A$. flavus present in PDA were successfully chelated by the same agents.

Among the chelating agents tested in the present study, EDTA was the most effective one against $A$. flavus. This agent inhibited $A$. flavus growth at varying degrees in all media tested. Inhibition rates recorded in CZA, PDA and fig-extract agar were 69.2-100, 41.7-81.0 and 0-18.6\%, respectively. Inhibition rates 
significantly increased as the concentration of EDTA increased in all media tested $(\mathrm{p}<0.05)$. A complete inhibition of mold growth was observed throughout the $6 \mathrm{~d}$ incubation period in CZA containing EDTA at $1.75 \mathrm{mM}$. Abrunhosa and Venancio [50] tested different doses of Na2-EDTA (0.1-10 mM) against $A$. carbonarius, $A$. ibericus, toxigenic and non-toxigenic strains of $A$. niger on Czapek yeast extract agar. The authors observed dose-dependent inhibitions of all molds and recorded a maximum inhibition rate of $89 \%$. De Lucca [51] reported that EDTA $(0-1600 \mu \mathrm{g} / \mathrm{mL})$ added to PDA inhibited the growth of various mold strains including A. flavus.

As mentioned before, A. flavus did not grow at all in CZA medium prepared without $\mathrm{NaNO}_{3}$ throughout the $6 \mathrm{~d}$ incubation period. We proposed that $\mathrm{NaNO}_{3}$ is absolutely necessary for mold since it is the only nitrogen source in CZA. EDTA could strongly inhibit the growth of A. flavus in CZA and a $100 \%$ inhibition was achieved when it is used at the highest concentration (1.75 $\mathrm{mM})$ tested in our assays. To explain this situation, a chelating process that takes place between EDTA and nitrate can be proposed. Thus, $\mathrm{NaNO}_{3}$ (the only nitrogen source found in the medium) might be transformed into an unavailable form for metabolic activities of the mold. However, this is unlikely to occur because both compounds (nitrate and EDTA) are negatively charged. An alternative mechanism is that EDTA could have a role in denitrification process and reduce nitrate to some antimicrobial compounds that are potentially effective against $A$. flavus. Denitrification can be defined as reduction of nitrate to nitrite, nitric oxide, nitrous oxide and nitrogen under aerobic or anaerobic conditions [52]. Maas et al. [53] reported that Fe (II) EDTA plays an important role in the biological denitrification process as a suitable electron donor. Nitric oxide, one of the main products of denitrification process, was shown to inhibit the growth of $A$. niger, $P$. italicum and Monilinia fructicola under in vitro conditions [54]. Nitrite, another potential product of denitrification, is a well-known antimicrobial compound which is effective against many organisms including molds [55]. Therefore, EDTA could start up a reaction -or a series of reactions- that result in the reduction of nitrate to some compounds with antimicrobial properties (nitrite, nitric oxide, etc.) and these compounds could be primarily responsible for the observed antifungal effect against $A$. flavus.

It can be clearly seen from Figure 3 that the most limited inhibitory effect of EDTA against $A$. flavus was in fig-extract agar. When used at the minimum tested concentration $(0.175$ $\mathrm{mM}$ ), even no inhibition was observed. In order to see if higher inhibition rates would be obtained in the food medium, we decided to test increased concentrations of EDTA in fig-extract agar. However, due to the low solubility of EDTA, Na2-EDTA was used in our following experiments.

Figure 4 shows the effect of different concentrations (1.75-8.75 $\mathrm{mM}$ ) of $\mathrm{Na}_{2}$-EDTA on radial growth of A. flavus in fig-extract agar during $6 \mathrm{~d}$ incubation at $30^{\circ} \mathrm{C}$. $\mathrm{Na}_{2}$-EDTA was found to be significantly effective in controlling the growth of $A$. flavus in fig-extract agar $(\mathrm{p}<0.05)$. Up to $96.6 \%$ inhibition was achieved when this agent was used at the maximum concentration tested $(8.75 \mathrm{mM})$. Inhibitory effect was relatively high at the beginning and gradually decreased during the rest of the incubation period at all $\mathrm{Na}_{2}$-EDTA concentrations tested. One explanation for this observation could be that $\mathrm{Na}_{2}$-EDTA extended the lag phase (adaptation to conditions) and thus delayed the onset of log phase (exponential growth) of A. flavus. Another reason could be that chelating ability of $\mathrm{Na}_{2}$-EDTA diminished with time and the required substances for growth (minerals, etc.) became more available in the medium. In addition, inhibition rates obtained with $\mathrm{Na}_{2}$-EDTA were higher than those obtained with EDTA when used at the same concentration. For instance; at $1.75 \mathrm{mM}$, the use of $\mathrm{Na}_{2}$-EDTA resulted in $24.7 \%$ inhibition whereas EDTA caused $18.6 \%$. These results show that Na2EDTA was more effective than EDTA in controlling $A$. flavus growth under in vitro conditions. A similar conclusion was drawn by Basaran [42] after her survey on A. parasiticus.

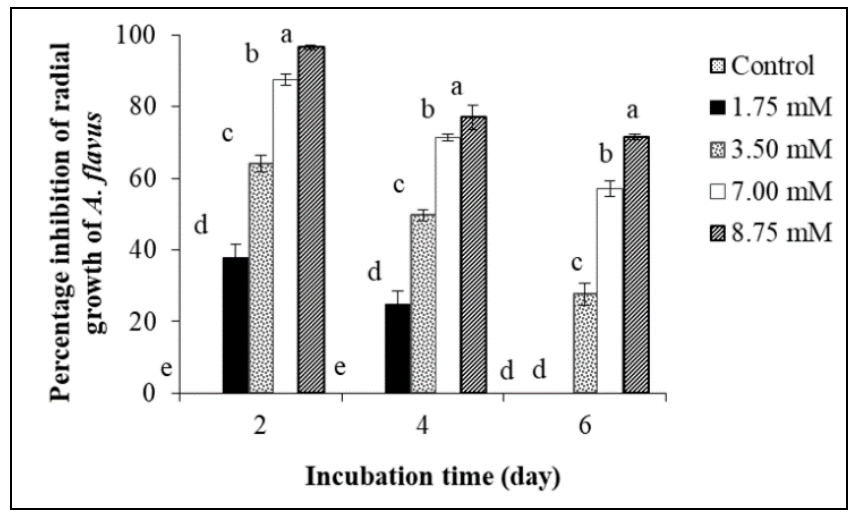

a: Data represent mean values and standard errors of five replicates. For each sampling day, mean values with different letters are significantly different according to Tukey's Multiple Range Test ( $\mathrm{p}<0.05)$.

Figure 4. The effect of different concentrations (1.75-8.75 mM) of $\mathrm{Na}_{2}$-EDTA on radial growth of $A$. flavus in fig-extract agar during $6 \mathrm{~d}$ incubation at $30^{\circ} \mathrm{C}$. a

\subsection{The effects of chelating agents on the $\mathrm{pH}$ values of the media}

It was reported that a $\mathrm{pH}$ value in the range of $3.4-10.0$ is required for the growth of toxigenic A. flavus [56]. Holmquist et al. [26] reported that maximum growth of $A$. flavus and $A$. parasiticus were observed at $\mathrm{pH} 5$ in corn and in Sabouraud Dextrose Agar. The $\mathrm{pH}$ values of the media could possibly be affected by the addition of chelating agents and $\mathrm{pH}$ is one of the determinative factors for mold growth. Moreover, chelating abilities of the agents could vary depending on the $\mathrm{pH}$ of the medium. For instance, enhanced chelating abilities were reported at low $\mathrm{pH}$ values for citric acid and at high $\mathrm{pH}$ values for EDTA [57]. Therefore, the $\mathrm{pH}$ values of the media amended with chelating agents were measured. The results are given in Table 3.

All the agents added to the media caused decreases in $\mathrm{pH}$ values. As the amounts of the agents added to the media were increased, the decreases in $\mathrm{pH}$ were more pronounced. It was also the case for EDTA which was found to be effective in inhibiting the growth of A. flavus in all media tested in a dosedependent manner. However, EDTA is known to be more efficient in chelating minerals at high $\mathrm{pH}$ values [57]. Therefore, alternative mechanisms other than chelating could be responsible for the success of EDTA in controlling growth of the mold. The minimum $\mathrm{pH}$ values were 4.47 and 3.82 which were measured in PDA amended with citric acid and phytic acid, respectively. PDA was the only media in which citric acid and phytic acid could inhibit $A$. flavus growth. In the light of these findings, two possible mechanisms could be proposed to explain the inhibition effectiveness of these agents. First, citric acid and phytic acid could form strong chelates with the substances required for mold growth due to high chelating abilities of these agents at low $\mathrm{pH}$ values. The second one could 
be attributed to disruption of intracellular $\mathrm{pH}$ balance of the mold in the presence of these agents.

Table 3. $\mathrm{pH}$ values of CZA, PDA and fig-extract agar medium amended with the different concentrations of citric acid, phytic acid, EDTA or Naz-EDTA. a

\begin{tabular}{|c|c|c|c|}
\hline Medium & $\begin{array}{c}\text { Chelating } \\
\text { agent }\end{array}$ & $\begin{array}{c}\text { Concentration } \\
(\mathrm{mM})\end{array}$ & $\mathrm{pH}$ \\
\hline \multirow{12}{*}{ CZA } & \multirow{4}{*}{ Citric acid } & 0 & $7.23 \pm 0.01$ \\
\hline & & 0.175 & $7.12 \pm 0.01$ \\
\hline & & 0.875 & $6.67 \pm 0.01$ \\
\hline & & 1.75 & $6.23 \pm 0.01$ \\
\hline & \multirow{4}{*}{ Phytic acid } & 0 & $7.22 \pm 0.01$ \\
\hline & & 0.175 & $7.08 \pm 0.01$ \\
\hline & & 0.438 & $6.56 \pm 0.02$ \\
\hline & & 0.875 & $5.65 \pm 0.01$ \\
\hline & \multirow{4}{*}{ EDTA } & 0 & $7.21 \pm 0.01$ \\
\hline & & 0.175 & $7.29 \pm 0.01$ \\
\hline & & 0.875 & $6.84 \pm 0.01$ \\
\hline & & 1.75 & $5.69 \pm 0.02$ \\
\hline \multirow{12}{*}{ PDA } & \multirow{4}{*}{ Citric acid } & 0 & $5.40 \pm 0.02$ \\
\hline & & 0.175 & $5.39 \pm 0.02$ \\
\hline & & 0.875 & $4.85 \pm 0.02$ \\
\hline & & 1.75 & $4.47 \pm 0.01$ \\
\hline & \multirow{4}{*}{ Phytic acid } & 0 & $5.43 \pm 0.01$ \\
\hline & & 0.175 & $4.92 \pm 0.01$ \\
\hline & & 0.438 & $4.42 \pm 0.01$ \\
\hline & & 0.875 & $3.82 \pm 0.01$ \\
\hline & \multirow{4}{*}{ EDTA } & 0 & $5.39 \pm 0.01$ \\
\hline & & 0.175 & $4.97 \pm 0.02$ \\
\hline & & 0.875 & $4.61 \pm 0.02$ \\
\hline & & 1.75 & $4.29 \pm 0.01$ \\
\hline \multirow{17}{*}{$\begin{array}{l}\text { Fig- } \\
\text { extract } \\
\text { agar }\end{array}$} & \multirow{4}{*}{ Citric acid } & 0 & $4.89 \pm 0.01$ \\
\hline & & 0.175 & $4.83 \pm 0.01$ \\
\hline & & 0.875 & $4.77 \pm 0.01$ \\
\hline & & 1.75 & $4.64 \pm 0.01$ \\
\hline & \multirow{4}{*}{ Phytic acid } & 0 & $4.90 \pm 0.01$ \\
\hline & & 0.175 & $4.82 \pm 0.02$ \\
\hline & & 0.438 & $4.72 \pm 0.01$ \\
\hline & & 0.875 & $4.52 \pm 0.01$ \\
\hline & \multirow{4}{*}{ EDTA } & 0 & $4.87 \pm 0.01$ \\
\hline & & 0.175 & $4.62 \pm 0.01$ \\
\hline & & 0.875 & $4.34 \pm 0.01$ \\
\hline & & 1.75 & $4.35 \pm 0.01$ \\
\hline & \multirow{5}{*}{$\mathrm{Na}_{2}$-EDTA } & 0 & $4.90 \pm 0.01$ \\
\hline & & 1.75 & $4.79 \pm 0.01$ \\
\hline & & 3.50 & $4.71 \pm 0.01$ \\
\hline & & 7.00 & $4.66 \pm 0.01$ \\
\hline & & 8.75 & $4.61 \pm 0.01$ \\
\hline
\end{tabular}

3.5 The effects of the absence of minerals on aflatoxin production by $A$. flavus

To determine the effects of the absence of minerals on aflatoxin production; modified CZA media prepared by excluding one of the components $\left(\mathrm{NaNO}_{3}, \mathrm{MgSO}_{4}, \mathrm{Fe}_{2}\left(\mathrm{SO}_{4}\right)_{3}, \mathrm{KCl}\right.$ or $\left.\mathrm{KH}_{2} \mathrm{PO}_{4}\right)$ were inoculated with toxigenic $A$. flavus and incubated for $21 \mathrm{~d}$ at $30^{\circ} \mathrm{C}$. The results are shown in Figure 5.

The concentrations of aflatoxin $\mathrm{B}_{1}$ and total aflatoxins $\left(B_{1}+B_{2}+G_{1}+G_{2}\right)$ determined in the control plates were $1.34 \pm 0.00$ and $2.61 \pm 0.03 \mathrm{ng} / \mathrm{g}$, respectively. The amount of aflatoxins produced in the media did not change significantly in case of excluding $\mathrm{NaNO}_{3}, \mathrm{KCl}$ or $\mathrm{KH}_{2} \mathrm{PO}_{4}(\mathrm{p}>0.05)$, but increased in the absence of $\mathrm{MgSO}_{4}$ or $\mathrm{Fe}_{2}\left(\mathrm{SO}_{4}\right)_{3} \quad(\mathrm{p}<0.05)$. The concentrations of aflatoxin $\mathrm{B}_{1}$ and total aflatoxins determined in CZA without $\mathrm{MgSO}_{4}$ were $3.46 \pm 0.16$ and $5.05 \pm 0.16 \mathrm{ng} / \mathrm{g}$, respectively. These values were $3.84 \pm 0.81$ and $5.75 \pm 1.88 \mathrm{ng} / \mathrm{g}$, respectively, for CZA without $\mathrm{Fe}_{2}\left(\mathrm{SO}_{4}\right)_{3}$. In early studies, it was reported that $\mathrm{Mg}$ and $\mathrm{Fe}$ added to the media caused an increase [23],[58] or a decrease [59]-[61] in the amount of toxin produced by $A$. flavus and A. parasiticus.

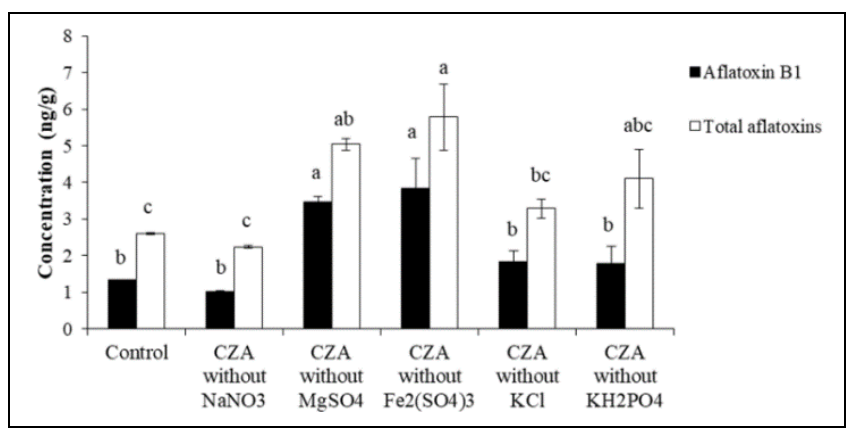

a: Data represent mean values and standard errors of three replicates, ii For a specific aflatoxin type, values with different letters are significantly different according to Tukey's Multiple Range Test ( $\mathrm{p}<0.05$ ).

Figure 5. Aflatoxin production by A. flavus in modified CZA media at the end of incubation at $30^{\circ} \mathrm{C}$ for $21 \mathrm{~d}$. a

We reported that no growth was observed throughout the $6 \mathrm{~d}$ incubation period in the medium prepared without $\mathrm{NaNO}_{3}$ and explained it could be due to the lack of the only nitrogen source in the medium. However, when these plates (containing medium prepared without $\mathrm{NaNO}_{3}$ ) were incubated for a longer period (up to $21 \mathrm{~d}$ ) to test aflatoxin production, we observed some mycelial growth on the plates. In these plates, we detected $1.03 \pm 0.01 \mathrm{ng} / \mathrm{g}$ aflatoxin $\mathrm{B}_{1}$ and $2.24 \pm 0.03 \mathrm{ng} / \mathrm{g}$ total aflatoxins at the end of 21- $\mathrm{d}$ of incubation. This situation may indicate that the mold which could not find any nitrogen source in the medium got stressed and produced aflatoxins. Some factors (drought, lack of nutrients, etc.) that negatively affect the growth of toxigenic Aspergillus strains were reported to cause stress on the mold and stimulate toxin production [62],[63]. On the other hand; nitrate, one of the main nitrogen sources used for growth was reported to suppress aflatoxin biosynthesis in toxigenic A. parasiticus [64]. Ehrlich and Cotty [65] reported that nitrate could affect aflatoxin biosynthesis via the expression of the key regulatory genes involved in the biosynthesis reactions.

\subsection{The effects of different media on aflatoxin production by $A$. flavus}

Aflatoxin $\mathrm{B}_{1}$ and total aflatoxins amounts produced by $A$. flavus in CZA, PDA and fig-extract agar were determined. The results are shown in Figure 6. PDA was the medium in which maximum amounts of aflatoxins were produced $(p<0.05)$. The concentrations of aflatoxin $\mathrm{B}_{1}$ and total aflatoxins determined in this medium were $532.95 \pm 3.35$ and $538.14 \pm 3.58 \mathrm{ng} / \mathrm{g}$, respectively. A. flavus was found to produce relatively lower amounts of aflatoxins $\left(53.69 \pm 2.56 \mathrm{ng} / \mathrm{g}\right.$ aflatoxin $\mathrm{B}_{1}$ and $55.87 \pm 2.58 \mathrm{ng} / \mathrm{g}$ total aflatoxins) in fig-extract agar while CZA was the medium in which the minimum toxin production $\left(1.13 \pm 0.05 \mathrm{ng} / \mathrm{g}\right.$ aflatoxin $\mathrm{B}_{1}$ and $2.47 \pm 0.11 \mathrm{ng} / \mathrm{g}$ total aflatoxins) was detected. Likewise, Fakruddin et al. [66] reported that $A$. flavus strains produced limited amount of aflatoxin $B_{1}(0.03 \mathrm{ng} / \mathrm{g})$ in CZA. Riba et al. [67] detected a maximum amount of only $0.24 \mathrm{ng} / \mathrm{g}$ aflatoxin $B_{1}$ in Czapek yeast extract agar. 


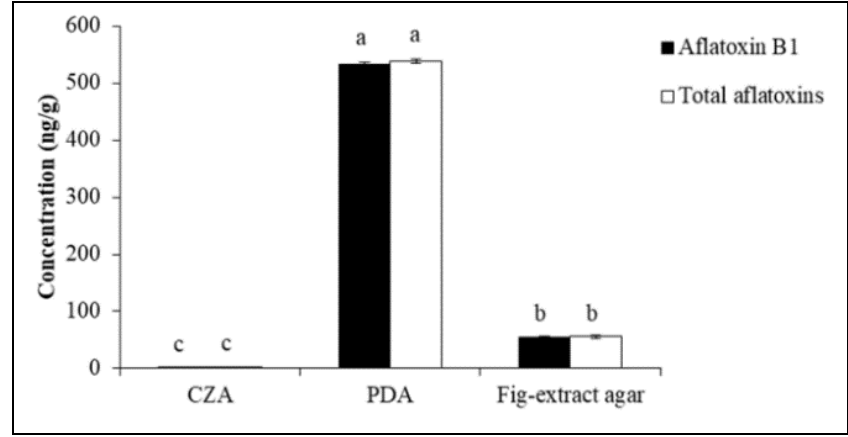

a: Data represent mean values and standard errors of three replicates. For a specific aflatoxin type, values with different letters are significantly different according to Tukey's Multiple Range Test $(\mathrm{p}<0.05)$.

Figure 6. Aflatoxin production by A. flavus in CZA, PDA and figextract agar at the end of incubation at $30^{\circ} \mathrm{C}$ for $21 \mathrm{~d}$. a

The results of the present study suggest that PDA and figextract agar are more suitable than CZA for both growth and aflatoxin production of $A$. flavus. This is probably due to the differences in the composition of different media such as carbon and nitrogen sources, vitamin and mineral contents, etc. After conducting experiments on a chemically defined medium, Davis et al. [23] reported that fructose resulted in the fastest growth of A. flavus and glucose resulted in the highest amounts of aflatoxins. Furthermore, the authors indicated that the mold grew faster in the presence of amino acids like aspartate, glycine, glutamate, etc.; however, complex nitrogen sources such as yeast extract and peptone, caused higher amounts of aflatoxin production. It is obvious that the compositions of the three media tested in the present study are quite different in terms of carbon and nitrogen sources, vitamin and mineral contents and this is one of the main reasons for observing varied growth rates and amounts of toxins. PDA, made from potato infusion and dextrose, is known as the principal media for fungal cultivation. Fungi can break down starch in potato into soluble sugars which can serve as a source of both carbon and energy. In addition, potato is a complex medium that provides nitrogen, enzymes, vitamins and mineral elements for fungal growth [68]. On the other hand; dried figs, which are the main component of fig-extract agar, were reported to have the best nutrient score among dried fruits [69]. Hence, these two media allowed efficient growth of fungi in the present study.

\subsection{The effects of chelating agents on aflatoxin production by $A$. flavus}

The most effective growth inhibitory doses of chelating agents (1.75 mM for citric acid and EDTA, $0.875 \mathrm{mM}$ for phytic acid) were tested for controlling aflatoxin production by A. flavus. The results obtained for aflatoxin $\mathrm{B}_{1}$ and total aflatoxins are given in Figure $7 \mathrm{a}$ and Figure $7 \mathrm{~b}$, respectively. The levels of both aflatoxin $\mathrm{B}_{1}$ and total aflatoxins were affected with the same trend in response to chelating agent treatments. The effects of chelating agents on aflatoxin production strongly depended on the medium type. For example; in fig-extract agar amended with citric acid, aflatoxin B1 and total aflatoxin amounts were 95.0 and $92.5 \%$ less than those in control plates. On the other hand; aflatoxin production amounts did not change in PDA $(p>0.05)$ and increased in CZA $(p<0.05)$ by addition of citric acid. Aflatoxin $B_{1}$ concentrations were $1.68 \pm 0.14$ and $1.23 \pm 0.06$ $\mathrm{ng} / \mathrm{g}$ in CZA with and without citric acid, respectively. The corresponding values were $2.90 \pm 0.13$ and $2.66 \pm 0.19 \mathrm{ng} / \mathrm{g}$ for total aflatoxins. Similarly, aflatoxin production was reported to be induced by adding $0.4 \%$ citric acid in CZA in an early study [70].

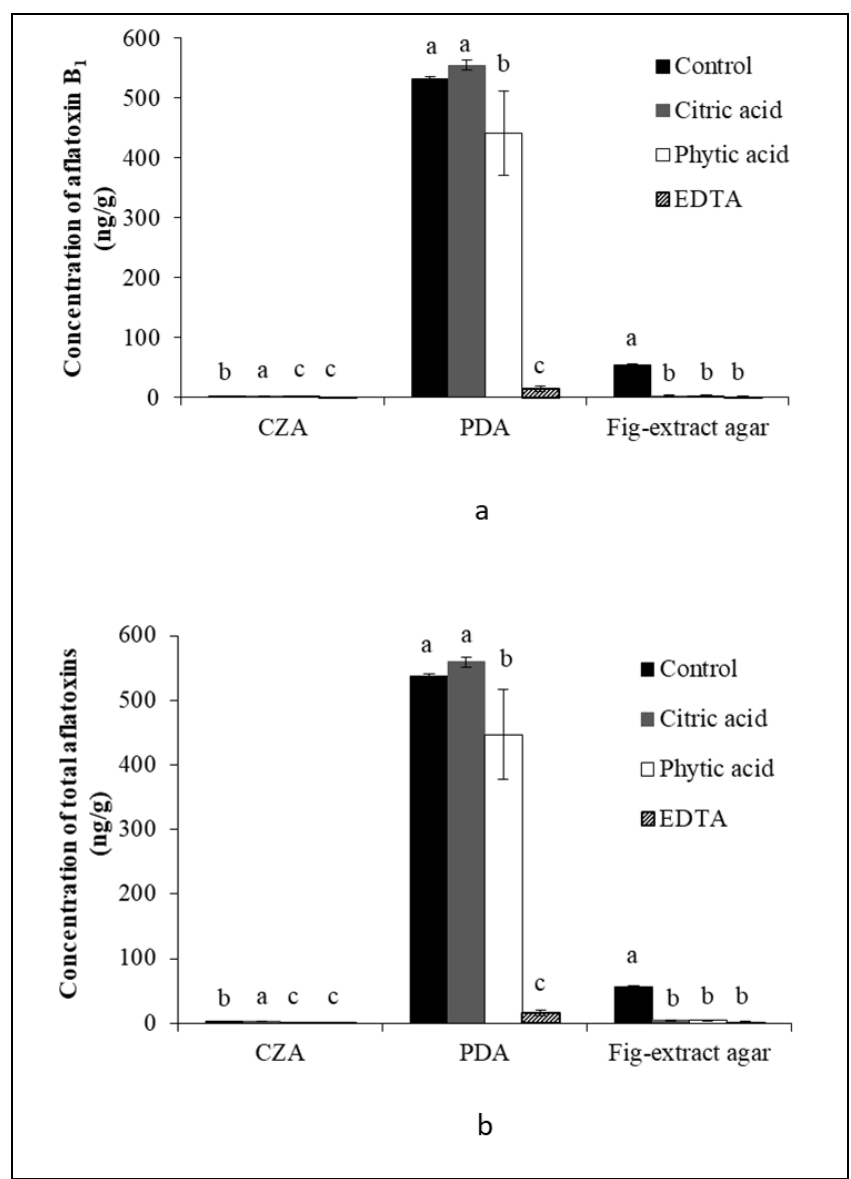

a: Data represent mean values and standard errors of three replicates, ii For a specific medium, values with different letters are significantly different according to Tukey's Multiple Range Test $(\mathrm{p}<0.05)$.

Figure 7. Aflatoxin $\mathrm{B}_{1}$. (a): and total aflatoxins. (b): Production by $A$. flavus on CZA, PDA and fig-extract agar in the presence of chelating agents at the end of incubation at $30{ }^{\circ} \mathrm{C}$ for $21 \mathrm{~d}$. a

We indicated that no growth was observed throughout the 6-d incubation period in CZA containing EDTA at $1.75 \mathrm{mM}$. However, when the incubation period was extended to $21 \mathrm{~d}$ to determine aflatoxin production in this medium, we observed a growth of $A$. flavus, even if just limited. EDTA inhibited the production of both aflatoxin B1 and total aflatoxins by $16 \%$ in CZA at the end of 21-d incubation. The rates of aflatoxin production inhibition obtained with EDTA and phytic acid in CZA were not significantly different ( $p>0.05)$.

In conclusion, according to our results, the growth and aflatoxin production of $A$. flavus widely differed according to the media used. Furthermore, the effectiveness of chelating agents in controlling mold growth and toxin production strongly depended on the type of the medium and the agent dose. More than $90 \%$ inhibition in aflatoxin production was achieved while mold growth was completely prevented in some cases by the use of chelating agents. All the agents used in this study have been classified as GRAS (generally recognized as safe) by the US Food and Drug Administration (FDA). Moreover; they are all water-soluble so their aqueous solutions can be easily prepared. These solutions can be applied directly to the fruit on the tree or to the soil around the tree. The latter application would be also useful since toxin-producing molds (A. flavus, $A$. 
parasiticus, etc.) are soil-borne fungi. It is obvious that studies that evaluate the efficacy of these agents against aflatoxinproducing molds in the orchard and investigate the effect of the treatment on fruit quality are strongly needed.

\section{References}

[1] Setlem K, Monde B, Ramlal S, Kingston J. "Immuno affinity SELEX for simple, rapid, and cost-effective aptamer enrichment and identification against aflatoxin $\mathrm{B}_{1}$ ". Frontiers in Microbiology, 7, 1909, 1-14, 2016.

[2] IARC-International Agency for Research on Cancer. IARC Monographs on the Evaluation of Carcinogenic Risks to Humans: Some Naturally Occurring Substances: Food Items and Constituents, Heterocyclic Aromatic Amines and Mycotoxins. Geneva, Switzerland, IARC, 1993.

[3] Sasanian N, Sari AA, Mortazavian AM. "Effect of Thymus daenesis and Satureja hortensis L. essential oils on quality properties of Iranian Doogh." Journal of Food Safety, Article Number e12527, 1-8, 2018.

[4] Zhai HC, Zhang SB, Huang SX, Cai JP. "Prevention of toxigenic fungal growth in stored grains by carbon dioxide detection". Food Additives and Contaminants: Part $A$, 32(4), 596-603, 2015.

[5] RASFF. "Rapid Alert System for Food and Feed Annual Report". European Commission. https://ec.europa.eu/food/sites/food/files/safety/docs/ rasff_annual_report_2015.pdf (18.12.2015).

[6] RASFF. "Rapid Alert System for Food and Feed Annual Report". European Commission. https://ec.europa.eu/food/sites/food/files/safety/docs/ rasff_annual_report_2016.pdf (08.12.2016).

[7] RASFF. "Rapid Alert System for Food and Feed Annual Report". European Commission. https://ec.europa.eu/food/sites/food/files/safety/docs/ rasff_annual_report_2017.pdf (28.12.2017).

[8] Shokri H. "Evaluation of inhibitory effects of citric and tartaric acids and their combination on the growth of Trichophyton mentagrophytes, Aspergillus fumigatus, Candida albicans, and Malassezia furfur". Comparative Clinical Pathology, 20, 543-545, 2011.

[9] Askarne L, Boubaker H, Boudyach EH, Aoumar AAB. "Use of food additives to control postharvest citrus blue mold disease". Atlas Journal of Biology, 2, 147-153, 2013.

[10] Ruhil S, Balhara M, Dhankhar S, Kumar M, Kumar V, Chhillar AK. "Advancement in infection control of opportunistic pathogen (Aspergillus spp.): Adjunctive agents". Current Pharmaceutical Biotechnology, $14,226-232,2013$

[11] Ruhil S, Kumar V, Balhara M, Malik M, Dhankhar S, Kumar $\mathrm{M}$, Chhillar AK. "In vitro evaluation of combination of polyenes with EDTA against Aspergillus spp. by different methods (FICI and CI model)". Journal of Applied Microbiology, 117, 643-653, 2014.

[12] Türkkan M, Erper İ. "Inhibitory influence of organic and inorganic sodium salts and synthetic fungicides against bean root to pathogens". Gesunde Pflanzen, 67, 83-94, 2015.

[13] Demir ST, Ozar AI, Gülseri O, Çoksöyler N, Konca R, Aksoy U, Düzbastılar M, Sağdemir A. "Investigations on Occurrence and Prevention of Aflatoxin and Ochratoxin Contamination in Figs in Aegean Region". Turkish Ministry of Agriculture and Rural Affairs, Ankara, Turkey, Project Report (Project No: KKGA-B-03-F-052), 1990.
[14] Anonymous.

"Sigma-Aldrich products". https://www.sigmaaldrich.com/catalog/product /sial/70185?lang=en\&region=TR (11.11.2018).

[15] Jimenes-Quero A, Pollet E, Zhao M, Marchioni E, Averous L, Phalip V. "Itaconic and fumaric acid production from biomass hydrolysates by Aspergillus strains". Journal of Microbiology and Biotechnology, 26, 1557-1565, 2016.

[16] Jain R, Valiante V, Remme N, Docimo T, Heinekamp T, Hertweck C, Gershenzon J, Haas H, Brakhage AA. "Tha MAP kinase MpkA controls cell wall integrity, oxidative stress response, gliotoxin production and iron adaptation in Aspergillus fumigatus". Molecular Microbiology, 82, 39-53, 2011.

[17] Karaca H, Pérez-Gago MB, Taberner V, Palou L. "Evaluating food additives as antifungal agents against Monilinia fructicola in vitro and in hydroxypropyl methylcelluloselipid composite edible coatings for plums". International Journal of Food Microbiology, 179, 72-79, 2014.

[18] FDA-United States Food and Drug Administration. "Department of Health and Human Services. BAM Media M127: Potato Dextrose Agar". https://www.fda.gov/food/foodscienceresearch/laborat orymethods/ucm063519.htm (12.11.2018).

[19] USDA-United States Department of Agriculture. "Agricultural Research Service, Natural Nutrient Database for Standard Reference Legacy Release". https://ndb.nal.usda.gov/ndb/foods/show/09094?fgcd= \&manu $=\&$ format $=\&$ count $=\& \max =25 \&$ offset $=\&$ sort $=$ defa ult\&order=asc\&qlookup=DRIED + FIGS $\% 2 C+U P C \% 3 A+72$ $2648711338 \& d s=\& \mathrm{t}=\& \mathrm{qp}=\& \mathrm{qa}=\& \mathrm{qn}=\& \mathrm{q}=\& i n g=$ (12.11.2018).

[20] Diener UL, Davis ND. "Aflatoxin Formation in Peanuts by Aspergillus flavus". Agricultural Experiment Station, Auburn University, AL, USA, Bulletin 493, 1977.

[21] Ellis WO, Smith JP, Simpson BK, Ramaswamy H, Doyon G. "Growth of and aflatoxin production by Aspergillus flavus in peanuts stored under modified atmosphere packaging (MAP) conditions". International Journal of Food Microbiology, 22, 173-187, 1994.

[22] Stroka J, Anklam E, Jörissen U, Gilbert J. "Immunoaffinity column cleanup with liquid chromatography using postcolum bromination for determination of aflatoxins in peanut butter, pistachio paste, fig paste and paprika powder: Collaborate study". Journal of the Association of Official Analytical Chemists International, 83, 320-340, 2000.

[23] Davis ND, Diener UL, Agnihotri VP. "Production of aflatoxin $\mathrm{B}_{1}$ and $\mathrm{G}_{1}$ in chemically defined medium". Mycopathologia, 31, 251-256, 1967.

[24] Aziz NH, Moussa AE. "Influence of white light, near UV irradiation and other environmental conditions on production of aflatoxin $\mathrm{B}_{1}$ by Aspergillus flavus and ochratoxin A by Aspergillus ochraceus". Nahrung, 41, 150154, 1997.

[25] Zohri AA, Saber SM, Mostafa ME. "Effect of selenite and tellurite on the morphological growth and toxin production of Aspergillus parasiticus var. globosus IMI 120920". Mycopathologia, 139, 51-57, 1997.

[26] Holmquist GU, Walker HW, Stahr HM. "Influence of temperature, $\mathrm{pH}$, water activity and antifungal agents on growth of Aspergillus flavus and A. parasiticus". Journal of Food Science, 48, 778-782, 1983. 
[27] Shahin AA, Aziz NH. "Influence of gamma rays and sodium chloride on aflatoxin production by Aspergillus flavus". Microbios, 90, 163-175, 1997.

[28] Stiles J, Penkar S, Plocková M, Chumchalová J, Bullerman LB. "Antifungal activity of sodium acetate and Lactobacillus rhamnosus". Journal of Food Protection, 65, 1188-1191, 2002.

[29] Abu-Mejdad NMJA. "Response of some fungal species to the effect of copper, magnesium and zinc under the laboratory condition". European Journal of Experimental Biology, 3, 535-540, 2013.

[30] Stone RW, Farrell MA. "Synthetic media for penicillin production". Science, 104, 445-446, 1946.

[31] Jackson MJ, Slininger PJ, Bothast RJ. "Effect of zinc, iron, cobalt, and manganese on Fusarium moniliforme NRRL 13616 growth and fusarin $\mathrm{C}$ biosynthesis in submerged cultures". Applied and Environmental Microbiology, 55, 649-655, 1989.

[32] Payne GA, Hagler WM. "Effect of specific amino acids on growth and aflatoxin production by Aspergillus parasiticus and Aspergillus flavus in defined media". Applied and Environmental Microbiology, 46, 805-812, 1983.

[33] Ehrlich KC, Kobbeman K, Montalbano BG, Cotty PJ. "Aflatoxin-producing Aspergillus species from Thailand". International Journal of Food Microbiology, 114, 153-159, 2007.

[34] Kranthi VS, Rao DM, Jaganmohan P. "Production of protease by Aspergillus flavus through solid state fermentation using different oil seed cakes". International Journal of Microbiology Research, 3, 12-15, 2012.

[35] Mehl HL, Cotty PJ. "Nutrient environments influence competition among Aspergillus flavus genotypes". Applied and Environmental Microbiology, 79, 1473-1480, 2013.

[36] McAlpin CE, Wicklow DT. "Culture media and sources of nitrogen promoting the formation of stromata and ascocarps in Petromyces Alliaceus (Aspergillus section Flavi)". Canadian Journal of Microbiology, 51, 765-771, 2005.

[37] Wang B, Han X, Bai Y, Lin Z, Qui M, Nie X, Wang S, Zhang F, Zhuang Z, Yuan J, Wang S. "Effects of nitrogen metabolism on growth and aflatoxin biosynthesis in Aspergillus flavus". Journal of Hazardous Materials, 15, 691-700, 2017.

[38] Morton SG, Eadie T, Llewellyn GC. "Aflatoxigenic potential of dried figs, apricots, pineapple, and raisins". JournalAssociation of Official Analytical Chemists, 62, 958-962, 1979.

[39] Ikechi-Nwogu CG, Elenwo EN. "Comparing the growth of fungal cultures on groundnut dextrose medium and potatoes dextrose medium". Journal of Science, 1, 46-52, 2012.

[40] Cotty PJ. "Comparison of four media for the isolation of Aspergillus flavus group fungi". Mycopathologia, 125, $157-$ 162, 1994.

[41] Schultz J, Muller W. "Effects of organic acids on mould growth in feed containing meat". Tierärztliche Umschau, 54, 98-101, 1999.

[42] Basaran P. "Antifungal effect of acids and surface active compounds for post-harvest control of Aspergillus parasiticus growth on hazelnut". Journal of Food Processing and Preservation, 35, 236-246, 2011.

[43] Wu HS, Chen XQ, Yang XN, Liu YD, Zhao GM. "In vitro growth of Fusarium oxysporum f. sp niveum in chemically defined citric acid". Asia Life Sciences, 20, 63-75, 2011.
[44] Dayi C, Ling X, Rong Y. "Phytic acid inhibits the production of aflatoxin $\mathrm{B}_{1}$ ". Journal of Food Processing and Preservation, 19, 27-32, 1995.

[45] Yang Q, Zhang H, Zhang X, Zheng X, Qian J. "Phytic acid enhances biocontrol activity of Rhodotorula mucilaginosa against Penicillium expansum contamination and patulin production in apples". Frontiers in Microbiology, 6, 1-9, 2015.

[46] Askarne L, Talibi I, Boubaker H, Serghini MA. "Effects of organic acids and salts on the development of Penicillium italicum: The causal agent of citrus blue mold". The Plant Pathology Journal, 10, 99-107, 2011.

[47] Gowda NKS, Malathi V, Suganthi RU. "Effect of some chemical and herbal compounds on growth of Aspergillus parasiticus and aflatoxin production". Animal Feed Science and Technology, 116, 281-291, 2004.

[48] Zhang H, Yang Q, Lin H, Ren X, Zhau L, Hou J. "Phytic acid enhances biocontrol efficacy of Rhodotorula mucilaginosa against postharvest gray mold spoilage and natural spoilage of strawberries". LWT-Food Science and Technology, 52, 110-115, 2013.

[49] Mahunu GK, Zhang H, Yang Q, Zhang X, Li D, Zhou Y. "Improving the biocontrol efficacy of Pichia caribbica with phytic acid against postharvest blue mold and natural decay in apples". Biological Control, 92, 172-180, 2016.

[50] Abrunhosa L, Venãncio A. "In vitro antifungal effect of EDTA disodium salt in tested black Aspergilli". Asian Journal of Biochemistry, 3, 176-181, 2008.

[51] De Lucca AJ. 2006. "In vitro inhibitory and fungicidal properties of EDTA for Aspergillus and Fusarium species". Interscience Conference on Antimicrobial Agents and Chemotherapy, San Francisco, CA, USA, 27-30 September 2006.

[52] Pilegaard K. "Processes regulating nitric oxide emissions from soils". Philosophical Transactions of the Royal Society B Biological Sciences, 368, 1-8, 2013.

[53] Maas P, Sandt T, Klapwijk B, Lens P. "Biological reduction of nitric oxide in aqueous Fe(II)EDTA solutions". Biotechnology Progress, 19, 1323-1328, 2003.

[54] Lazar EE, Wills RBH, Ho BT, Harris AM, Spohr LJ. "Antifungal effect of gaseous nitric oxide on mycelium growth, sporulation and spore germination of the postharvest horticulture pathogens, Aspergillus niger, Monilinia fructicola and Penicillium italicum". Letters in Applied Microbiology, 46, 688-692, 2008.

[55] Stanojevic D, Comic L, Stefanovic O, Solujic-Sukdolak S. "Antimicrobial effects of sodium benzoate, sodium nitrite and potassium sorbate and their synergistic action in vitro". Bulgarian Journal of Agricultural Science, 15, 307 311, 2009.

[56] Fratamico PM, Bhunisa AK, Smith JL. Foodborne Pathogens Microbiology and Molecular Biology. $1^{\text {st }}$ ed. Norwich, England, Academic Press, 2005.

[57] Gur E, Demirag K. Chelating Agents. Editor: Altug T. Food Additives, 193-199, İzmir, Turkey, Sidas Publishing, 2009.

[58] Reddy TV, Viswanathan L, Venkitasubramanian TA. "Factors affecting aflatoxin production by Aspergillus parasiticus in a chemically defined medium". Journal of General Microbiology, 114, 409-413, 1979.

[59] Marsh PB, Simpson ME, Trucksess MW. "Effects of trace metals on production of aflatoxins by Aspergillus parasiticus". Applied Microbiology, 30, 52-57, 1975. 
[60] Tiwari RP, Mittal V, Bhalla TC, Saini SS, Singh G, Vadehra DV. "Effect of metal ions on aflatoxin production by Aspergillus parasiticus". Folia Microbiologica, 31, 124-128, 1986.

[61] Cuero R, Ouellet T, Yu J, Mogongwa N. "Metal ion enhancement of fungal growth gene expression and aflatoxin synthesis in Aspergillus flavus: RT-PCR characterization". Journal of Applied Microbiology, 94, 953-961, 2003.

[62] Guo B, Chen ZY, Lee RD, Scully BT. "Drought stress and preharvest aflatoxin contamination in agricultural commodity: Genetics, genomics and proteomics". Journal of Integrative Plant Biology, 50, 1281-1291, 2008.

[63] Schmidr-Heydt M, Magan N, Geisen R. "Stress induction of mycotoxin biosynthesis genes by abiotic factors". FEMS Microbiology Letters, 284, 142-149, 2008.

[64] Kachholz T, Demain AL. "Nitrate repression of averufin and aflatoxin biosynthesis". Journal of Natural Products, 46, 499-506, 1983.
[65] Ehrlich KC, Cotty PJ. "Variability in nitrogen regulation of aflatoxin production by Aspergillus flavus strains". Applied Microbiology and Biotechnology, 60, 174-178, 2002.

[66] Fakruddin M, Chowdhury A, Hossain MN, Ahmed MM. "Characterization of aflatoxin producing Aspergillus flavus from food and feed samples". Springerplus, 4, 2-6, 2015.

[67] Riba A, Bouras N, Mokrane S, Mathieu F, Lebrihi A, Sabaou N. "Aspergillus section Flavi and aflatoxins in Algerian wheat and derived products". Food and Chemical Toxicology, 48, 2772-2777, 2010.

[68] Wongjiratthiti A, Yottakot S. "Utilisation of local crops as alternative media for fungal growth". Pentanika Journal of Tropical Agricultural Science, 40, 295-304, 2017.

[69] Barolo MI, Mostacero NR, Lopez SN. "Ficus carica L. (Moraceae): An ancient source of food and health". Food Chemistry, 164, 119-127, 2014.

[70] Wildmann JD, Stoloff L, Jacobs R. "Aflatoxin production by a potent Aspergillus flavus Link isolate". Biotechnology and Bioengineering, 9, 429-437, 1967. 